\title{
DỨBin
}

Technological University Dublin ARROW@TU Dublin

2014

\section{Community Based Learning}

\author{
Greg Burke \\ Technological University Dublin, Greg.Burke@tudublin.ie
}

Follow this and additional works at: https://arrow.tudublin.ie/ltcassess

Part of the Higher Education Commons

\section{Recommended Citation}

Burke, G. (2020) Community Based Learning, Learning,Teaching \& Technology Centre, Technological University Dublin

This Other is brought to you for free and open access by the Learning \& Teaching Practice Exchange at ARROW@TU Dublin. It has been accepted for inclusion in Assessment \& Feedback Cases by an authorized administrator of ARROW@TU Dublin. For more information, please contact arrow.admin@tudublin.ie, aisling.coyne@tudublin.ie,gerard.connolly@tudublin.ie.

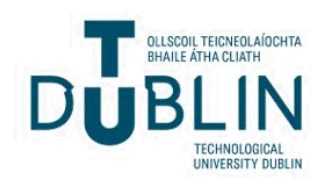




\section{Assessment \& Feedback Use Cases}

\section{COMMUNITY BASED LEARNING}

\section{Author: Greg Burke}

Date: 2014

This use case describes how one assessment method was designed and implemented by a lecturer or a group of lecturers in DIT. The use case was compiled from an interview conducted as part of DIT's RAFT project (2013-14), the aim of which was to provide a database of assessment practices designed and implemented by academic staff across DIT. 


\section{Lecturer}

Greg Burke

\section{Programme and year on which assessment was offered}

- BSc Nutraceuticals in Health and Nutrition, Year 3

- BSc Food Innovation, Year 3

- BSc Environmental Health, Year 3

\section{Description}

Hygiene \& HACCP Audit of a Food Premises (or part thereof) of your choice.

\section{Why did you use this Assessment?}

Multiple reasons including:

- Community based, practical task, requiring assimilation of theory (covered in lectures and published standards), applying it to a specific location and writing it up as an Audit Report with appropriate recommendations.

- Integrates material from multiple modules (Law, micro, business etc)

- Solves all plagiarism related issues as each student identifies their own site in advance, so no two can do same site. (Even when this has happened, I received two different reports).

- Correcting is much more engaging and interesting as each site and report is different.

\section{Why did you change to this form of assessment?}

- I have been gradually developing different assessments requiring different levels of auditing skills depending on the proficiency of the group (determined by course and year/level).

- Before that it was a HACCP (Food Safety) study of a product, but the availability of such case studies on web forced me to change or I was going to be awarding marks for downloading.

- To further cement the individualised nature of the work, I am going to experiment with a mini presentation outlining the key findings next time round which opportunity for both the class and myself to question the presenter. 


\section{How do you give feedback to students?}

- Individual comments on written Audit Reports handed up to me. Both positive and critical comments made. Marking explained in 2-3 lines outlining best and worst aspects of the Report.

- Reports and marking then handed back to students, ideally before end of semester, at worst before exam in that module.

- More dramatic (anonymous) examples of best and worst Auditing practice marked on Assessments and then fed back into the next lecture series as 'thing to do'/'not to do'. This is now being refined into a FAQ on what to do/not do and examples of what gets best and lowest marks for future use.

\section{What have you found are the advantages of using this form of assessment?}

- Student engagement.

- Students like it.

- Reflective comments almost always positive

- Community based, done at home or work out of college time.

- I have never come across an attempted fake or download yet.

- Marking process clarifies areas where students are confused, such as between Statutory Instruments or SI's and IS's or National Standards

- Brilliant examples and micro case studies generated which with students permission (only sought after marks returned) may be used for teaching or assessment purposed in future.

- Moves the academic level from factual data to analysing real world environments with all their complications and synthesising appropriate practical recommendations.

\section{What have you found are the dis-advantages of using this form of assessment?}

- Some get so enthusiastic they write double the max, compounding the correcting load.

- Requires covering a lot of basic material quickly, early in semester so they have the theory.

- Some students have no experience of working with food or drink and cannot readily come up with a site. We discuss the options available to each individually and look beyond the obvious as long as the principles are being applied.

- Some students shown all info, others given very restricted access, so marking scheme has to be flexible enough to deal with this and to grade the effectiveness of what they did do/had access to.

- Writing an appropriate marking scheme is not easy. 
If another lecturer was using this assessment method would you have any tips for them?

- Don't be afraid to experiment

- Do start with core areas and skills to your module and preferably to the students degree and likely area of future work

- Explain how you are going to mark the assessment in the assessment specification and reinforce that in lecture time with images and examples. In my case I have to explain that it's not how clean or dirty a premises is that matters, it's how well they describe what they are finding and the appropriateness of their recommendations.

\section{Do you have any feedback from students about this assessment?}

- Yes, many even admit they have enjoyed doing it as it gives them a feel for what they could be doing as a graduate.

- They also like the way it ties together material from different modules.

- Some report difficulties with owners/managers and access to sites and data. I suspect this occurs where the Owner/Manager feel threatened by the student's knowledge and is not smart enough to avail of free advice, which by and large is correct.

- Others admit to not being well enough prepared (but it's a learning exercise, perfection not expected).

- Most say they have learned a lot and have found it a positive and professionally developing experience.

- In some cases, management have adopted the students recommendations and have improved their level of compliance, hygiene and safety as a result.

- Most like the marks they get and the explanation of why they have received those marks. The Assessment marks are invariably higher than the exam marks and last Semester came out mid range in comparison to other modules.

- Low marks are strongly correlated with low attendance. 


\section{Additional Comments}

- Every time I pass the teaching rooms when exams are in session, there is a horrible atmosphere/vibe around.

- With assessment we can do much better. The process also involves students using their soft/broad/ transferrable skills too and marks better reflect what employers want.

- Even the feedback session has a positive buzz and if the marking scheme is at all transparent, students see why they have the grade they have and accept their mark, even if it's not the mark they would like.

\section{Additional Resources}

Assignment Description (see below) 


\section{1/3 BSc Environmental Health 2012-2013 \\ Module TFFS3004 Food Quality\& Safety Systems}

\section{Assignment Greg.Burke@dit.ie value 30\% of Module}

\section{Assessment title: "Hygiene and HACCP Audit Of A Food Premises Of Your Choice"}

Please address each of the following headings which carry approx $20 \%$ of the assessment marks, though the assessment is marked as a whole to increase flexibility of marking.

1. Overview of the premises site summarising location, scale of operations, layout analysing the risks from surrounding environment including adjacent premises etc.

2. Analyse how well 5 relevant pre-requisites are maintained, using an appropriate Best Practice guide document such as IS 340:2007 or IS 341:2007.

3. Review the effectiveness of the HACCP system in place, paying particular attention to the appropriateness of 'Critical Limits', frequency of Monitoring and effectiveness of 'Corrective Action'.

4. Devise appropriate Recommendations to correct deficiencies noted in

- Effectiveness and reliability of Prerequisite programmes

- Effectiveness and reliability of CCP'S, recording, \& corrective actions.

5. Reflection on this Assessment:

- What have you learned about Auditing?

- What you would do differently if you had to do it again?

- What have you learned about your own skills?

Hardcopy Submission date 9 $^{\text {th }}$ January 2013 to Greg Burke Postbox, Sackville Place.

Also to Food Quality and Safety Systems Blackboard saved as 'Your Name.doc" Only Microsoft Word 2010 or older formats are readable. 


\section{Notes}

1. The premises need not be named if confidentiality is deemed by student to be appropriate.

2. The auditor will need to be familiar as possible with the layout and operations in all areas.

3. The report should be suitably scientific, contain no casual phrases and address causes, not symptoms.

4. Note: Should you find that PrP'S and CCP's are mislabelled or mixed up, please suggest improvements.

5. Size: The maximum size of the submitted document will be less than or equal to 8 (typed) pages, including cover, text, HACCP summary tables, sources referenced etc,.

6. The responsibility for submitting assessments rests with students. Responsibility for marking (out of 100, after reading the first 8 pages) and submitting to Electronic Grade Book rests with Lecturer. The default mark for no submission is zero.

7. School "Late Assessments Policy" applicable and Dublin Institute of Technology Plagiarism regulations apply.

8. Suggested reference documents include: IS 340:2007 for Catering, IS 341:2007 for Retailing, BRC Global Food Standard 6, 2011 for processing facilities, Also FSAI Gn 1, 11 and 12 may be useful. 